\title{
赤色辛口系米味噌における大豆蒸熟と熟成温度が 香気成分形成に及ぼす影響
}

\author{
賀来由夏* ・菅原悦子* ・高橋 清**
}

\begin{abstract}
Effect of the Manufacturing Process (the Hardness of Steamed-cooked Soybeans and the Temperature During the Aging Process) on the Formation of Aroma Components of Red Salty Rice Miso with Aging
\end{abstract}

\author{
Yuka Kaku* Etsuko Sugawara* and Kiyoshi Takahashi** \\ * Faculty of Education, Iwate University, 3-18-33 Ueda, Morioka, Iwate 020-8550 \\ ** Miyagi Miso and Soysauce Industrial Cooperation, 2-11-1, Ichiban-cho, Aoba-ku, \\ Sendai, Mivagi 980-0811
}

\begin{abstract}
The influence of the hardness of steam-cooked soybeans and of the temperature during the aging process was investigated on the formation of aroma compounds of red salty rice miso. Soybeans with two levels of hardness were prepared by the conditions used for steam-cooking, and the temperature during aging process was set at $25^{\circ} \mathrm{C}$ or $30^{\circ} \mathrm{C}$. The resulting four types of miso sample were analyzed after being aged for $0,30,60,90,120,150$ and 180 days. The principal constituents of each miso sample were evaluated by the standard method for miso analysis. An aroma concentrate of each miso sample was prepared by adsorption to a porous polymer, and then analyzed by gas chromatography (GC) and gas chromatography-mass spectrometry (GC-MS). 3-Methyl-1-butanol and 2-phenylethanol, which are quantitatively the main aroma compounds in red salty rice miso, and methionol, which is one of the characteristic compounds in miso, each showed a high concentration during the aging process at $25^{\circ} \mathrm{C}$. In contrast, 4-hydroxy-2(or 5)-ethyl-5(or 2)-methyl-3(2H)-furanone(HEMF), a character-impact compound in miso, was present in greater quantity during the aging process at $30^{\circ} \mathrm{C}$. The concentrations of these aroma components were little influenced by the hardness of the steamcooked soybeans. The value for $\mathrm{Y}(\%)$ in the chromaticity diagram decreased markedly during the aging process at $30^{\circ} \mathrm{C}$. The formation of HEMF was considered to relate to the decrease of the value for $\mathrm{Y}(\%)$. (Received May 1, 2000 ; Accepted Sep. 14, 2000)
\end{abstract}

味噌によって香りはその品質を左右する重要な因子で ある，米味噌は大豆，米麹，食塩を原料とし，製麦匊，大 豆の加熱など様々な工程を経て製造されており，各工程 の条件が味噌の香りをはじめとする品質に重大な影響を 及ぼす。味増の香気成分については多くの研究いー3があ り，製品となった味噌の香気は 200 種以上の成分より構 成されていることが報告"されれている，著者ららーて は $\operatorname{HEMF}$ (4-hydroxy-2(or 5)-ethyl-5(or 2)-methyl-3(2H)- furanone）と methionol が赤色辛口系米味噌を代表と する発酵型米味増や麦味増の特有香気成分であることを 明らかにした。しかしながら，これら香父成分の製造条 件による变動については解明されていない。本研究では 赤色辛口系味増の香気成分形成に影響を抢よぼす様々な 製造条件の中から，特に大豆の㧈熱条件之熟成温度の”. つに焦点をしほり，特有香気成分である HEMF と methionol やその他の香気成分の熟成中の消長への影

* 岩手大学教育学部（干020-8550 岩手県盛岡市上田 3-18-33）

** 宮城県味増酱油工業協同組合（テ980-0811 宮城県仙台行青葉区一番町 2-11-1） 
響を明らかにすることを目的とした。また，味増を醸造 する際に品質管理等の目的で測定される一般成分や色調 の変動と香気成分の消長との関係の解明も試みた.

\section{実 験 方 法}

\section{1. 試 料}

大豆は1996 年産アメリ力産白目大豆, 乾燥時重量 $2.50 \mathrm{~kg}$ を使用した。洗穀後, 一晚浸漬させ, 加圷蒸熟好 理条件を变化させて，大豆硬度を柔らかい $300 \mathrm{~g}$ と硬い $700 \mathrm{~g}$ に設定した. 大豆硬度 $300 \mathrm{~g}$ の加圧蒸熟処理条件 は $0.75 \mathrm{~kg} / \mathrm{cm}^{2} \cdot 37$ 分間, 硬度 $700 \mathrm{~g}$ が $0.75 \mathrm{~kg} / \mathrm{cm}^{2} \cdot 13$ 分間であった。 大豆硬度は蒸熟後 $40^{\circ} \mathrm{C}$ に冷却した処理 大豆を $2 \mathrm{~kg}$ の台科に乗せ，人差し指で押し，大豆が潰れ たときの目盛りを読み, 20 粒の平均とした。一般的に, 大豆硬度 $800 \mathrm{~g}$ 以上の処理大豆を使用した場合にはざら つきが生じ，硬度 $300 \mathrm{~g}$ 以下ではネバルとともに発酵不

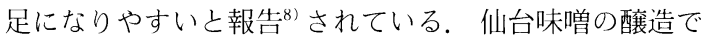
は大豆硬度は $400 \mathrm{~g}$ の場合が多く, $300 \mathrm{~g}$ としていると ころもある. また, 大豆硬度 $700 \mathrm{~g}$ は信州味増の醸造に 一般的に用いられている ${ }^{8)}$. 従って, 本研究では実際に 赤色辛口系米味増の醸造に使用されている最屯柔らかい 蒸煮大豆と硬い蒸煮大豆を用いた。

米は夕イ産の丸米 $2.00 \mathrm{~kg}$ を使用し製靝した。食塩の 使用量は $1.25 \mathrm{~kg}$ であった. 蒸熟処理大豆, 麹, 食塩を混 合し，その際種水 $900 \mathrm{~m} l$ を添加した．種水は耐塩性酵母 Zygosaccharomyces rouxii (商品名「まろい 1 株」(0)11') を味増 $1 \mathrm{~g}$ あたり $10^{5}$ 個になるように調製した。この結 果，原料配合は靝歩合 8 歩，食塩 $12.5 \%$ ，水分 $47 \%$ と なった。仕込み量は各 $10 \mathrm{~kg}$ とした。

熟成温度は $25^{\circ} \mathrm{C}$ と $30^{\circ} \mathrm{C}$ とた。一般的に，鍻の酵素 による分解作用之微生物の発酵とのバランスが大切な辛 口米味噌では有用微生物の生育に適温である $30^{\circ} \mathrm{C}$ 前後 で熟成させる ${ }^{8)}$. 本研究に用いた酵母の生育温度試験で は, $27.5^{\circ} \mathrm{C}$ で最む増殖がよかった ${ }^{10)}$. そこで, 適温より高 い $30^{\circ} \mathrm{C}$ と低い $25^{\circ} \mathrm{C}$ に設定し, 熟成温度の影響を検討し た.

以上により, 大豆硬度と熟成温度の組み合わせで以下 の 4 種類の味増を調製した。大豆硬度 $300 \mathrm{~g}$ - 管理温度 $25^{\circ} \mathrm{C}$, (以下 $300 \mathrm{~g}-25^{\circ} \mathrm{C}$ 上略す), 大豆硬度 $700 \mathrm{~g}$ - 管理温 度 $25^{\circ} \mathrm{C}$ (以下 $700 \mathrm{~g}-25^{\circ} \mathrm{C}$ 之略す), 大豆硬度 $300 \mathrm{~g}-$ 管理 温度 $30^{\circ} \mathrm{C}$ (以下 $300 \mathrm{~g}-30^{\circ} \mathrm{C}$ と略す), 大豆硬度 $700 \mathrm{~g}-$ 管 理温度 $30^{\circ} \mathrm{C}$ (以下 $700 \mathrm{~g}-30^{\circ} \mathrm{C}$ と略す) の 4 種類である. 熟成期間は 6 ケ月とし，仕込み直後から 30 日間隔でサ ンプリングを行った. 従って, 仕込み直後, $30,60,90$,
120，150，180日目の 7 回サンプリングし，合計 28 種を 試料として用いた。

\section{2. 香気濃縮物の調製及び香気成分の分離 - 同定}

香気濃縮物は著者ら ${ }^{22}$ によって味噌の香気研究にそ の有用性が報告されているポーラスポリマーを用いた力 ラム濃縮法で調製した。試料味噌 $40 \mathrm{~g}$ に蒸留水 $160 \mathrm{~m} l$ を添加して $20 \%$ 䀣濁液とし, 冷却遠心分離器 (HIT ACHI 18PR-52) で, $5^{\circ} \mathrm{C}, 5000 \mathrm{rpm}$ で 15 分間処理 し上澄液を得た。これを精製したTenax TA $2.5 \mathrm{~g}$ を充 填した内径 $1 \mathrm{~cm}$ のガラスカラムに流し，既報 ${ }^{12)}$ と同様 に処理して香気濃縮物を得た。同一試料に対して 3 回, 実験を繰り返した。

得られた香気濃縮物はガスクロマトグラフ $(\mathrm{GC})$, 及 び GC に直結したマススペクトロメーター（GC-MS）を 用いて分析した。分析条件は既報 ${ }^{12)}$ と同様である。各香 気成分の濃度は GC 分析の結果をもとに内部標準物質 （n-decyl alcohol）とのピーク面積比から，試料とした 味噌の重量に対する ppm で算出した。

\section{3. 一般成分, 色調の測定方法}

試料は 30 日間隔でサンプリングした際に基準味噌分 析法 ${ }^{13)}$ に従って一般成分を分析した。分析項目は水分, 食塩, 水溶性窒素, アミノ態窒素, 全窒素, 直接還元糖, 滴定酸度，pH，エ夕ノールおよび色調であった。測色は 日本電色工業(株) 製測色々度計 1001 型を用い, Y (\%), $\mathrm{x}, \mathrm{y}$ で表示した。

\section{結果および考察}

\section{1. 味増熟成中の香気成分の消長}

Fig. 1 に $300 \mathrm{~g}-30^{\circ} \mathrm{C}$ の 90 日目の試料から調製した香 気濃縮物を分析した際のガスクロマトグラムを示した。 試料とした 4 種類の各熟成段階の味噌から得られたガス クロマトグラムを比較検討し，99のピークを選択して各 種香気成分の濃度を算出し, 香気成分の生成量を比較し た. 特に, 3-methyl-1-butanol (ピーク No. 17), 2-phenylethanol (ピーク No. 65), methionol (ピーク No. 51）と HEMF（ピーク No. 76）に注日し，その変動につ いて検討した。

(1) 3-methyl-1-butanol と2-phenylethanol の変動 すっきりとしたアルコール香の 3-methyl-1-butanol とバラ様の芳香をむつ2-phenylethanol ${ }^{14)}$ の濃度は熟成 中のいずれの段階においても，検出された 99 ピークの 香気成分の濃度を合計した值の 40 ～65\%を占めており， 量的に主要な香気成分であることが確認された。従っ て，これら 2 成分の变動は醇造された味噌の香気の特徵 


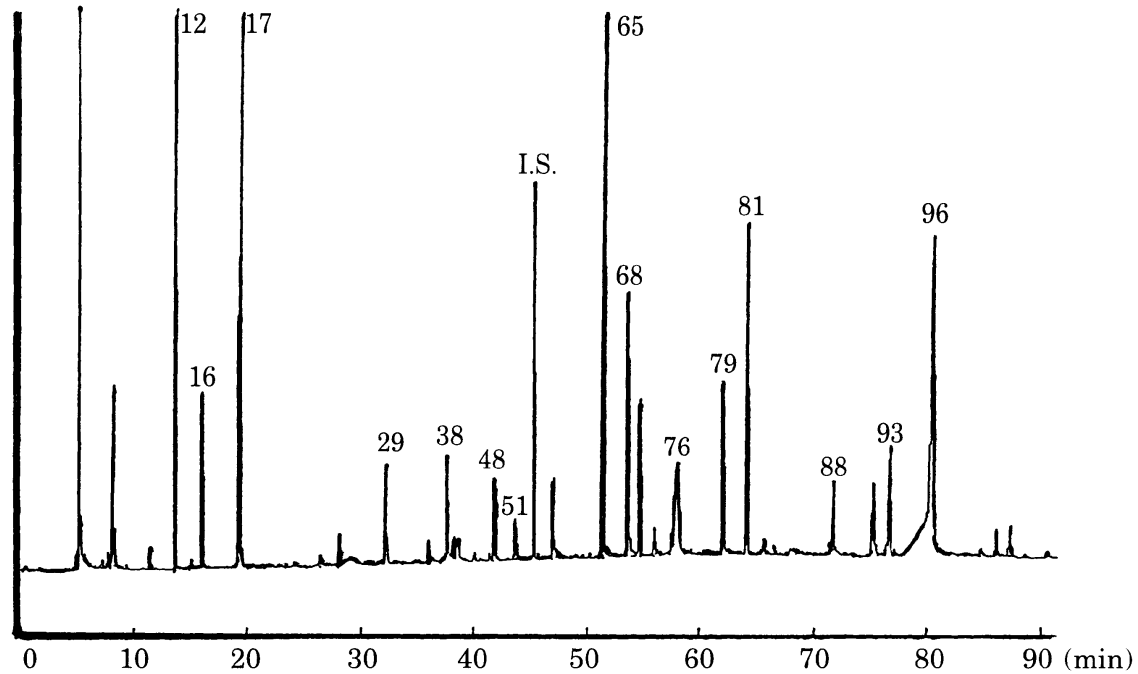

Fig. 1 A gas chromatogram of the aroma concentrate of miso $\left(300 \mathrm{~g}-30^{\circ} \mathrm{C}\right)$ aged for 90 days after the miso mash

Peak No. 17 : 3-methyl-1-butanol, Peak No. 51 : methionol, Peak No. 65 : 2-phenylethanol, Peak No.76: HEMF, I.S. : internal standard.

に影響を与えるとともに，香気成分全体量の変動をも示 唆すると考えられた。 そこで 3-methyl-1-butanol と2phenylethanol の熟成中の濃度変化を Fig. 2 に示した. これら両化合物は，熟成の初期段階から高濃度に生成さ

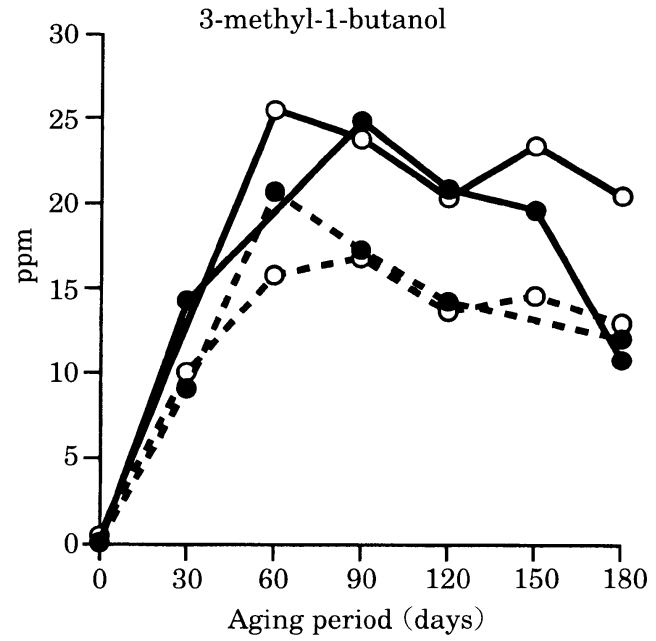

れるが大豆硬度の影響はほとんよ゙受けないことが判明し た。 また両化合物の濃度は, $25^{\circ} \mathrm{C}$ 区が $30^{\circ} \mathrm{C}$ 区よりも全期

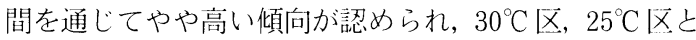
もに60〜90日目に最高值に達することが判明した。

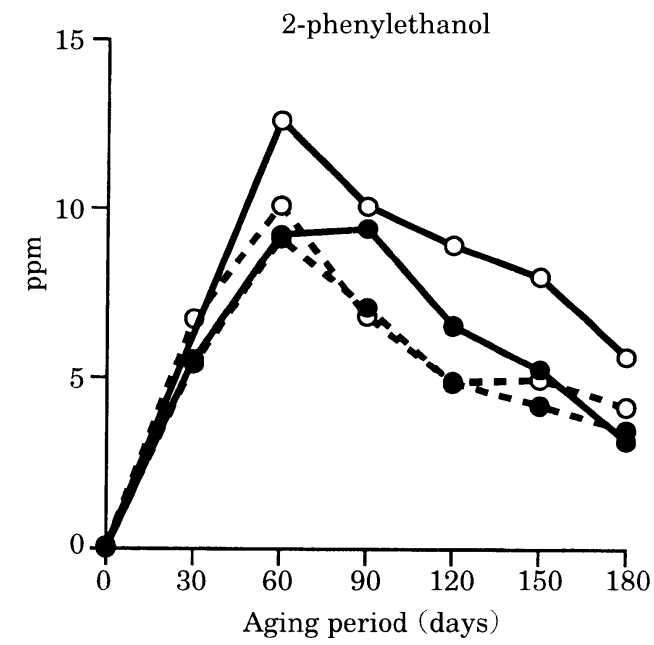

Fig. 2 Changes of the concentrations of quantitatively main aroma compounds in miso during the aging process

- $300 \mathrm{~g}-25^{\circ} \mathrm{C} ;-\bigcirc-, 700 \mathrm{~g} \cdot 25^{\circ} \mathrm{C} ;$

$\cdots, 300 \mathrm{~g}-30^{\circ} \mathrm{C} ; \cdots \bigcirc \cdots, 700 \mathrm{~g}-30^{\circ} \mathrm{C}$ 


\section{（2）特有香気成分の変動}

特有香気成分のひとつである methionol はやや香ば しく，濃度によっては酱油様である(1)。味噌熟成中の methionol の濃度变化を Fig. 3 に示した. methionol の全期間を通しての变動は先に述べた 3-methyl-1 butanol 之類似し，大豆硬度より熟成温度の影響が大き いことが示唆された。 $30^{\circ} \mathrm{C}$ 区では 60 日目にはピークを 迎えたが， $25^{\circ} \mathrm{C}$ 区は 120 日目がピークとなり，その時の 濃度は $30^{\circ} \mathrm{C}$ 区の約 2 倍であり，低温でゆっくりと熟成 した場合に高濃度になる可能性が示唆された。

HEMFは官能的には甘いカラメル様の強烈な香気で, 味噌の香気に甘さをもたらす成分で，閾值は $0.04 \mathrm{ppb}$ 以 下であると報告5)されている。熟成中の HEMF の濃度 变化を Fig. 4 に示した. HEMF はいずれの試料におい ても仕込み直後の味増からは全く検出されなかった。熟 成中の HEMF の生成は大豆硬度には影響されなかった が，熟成温度に大きく影響された。 $30^{\circ} \mathrm{C}$ 区に㧍ける HEMF 濃度は仕込み直後加急激に上昇し，60日目に 最高值を示したがそれ以降は急激に低下した。HEMF は不安定な化合物であるため，熟成中に一部分解する可 能性のあることが示唆された。 $25^{\circ} \mathrm{C}$ 区においては，仕込 み後ゆるやかに上昇し 120 日目に濃度のピークを迎えた が，ピーク時の濃度は $30^{\circ} \mathrm{C}$ 区の $1 / 3$ に過ぎなかった，清 酒などの醅造食品に屯共通する香気成分の 3-methyl-1butanol や2-phenylethanol は $25^{\circ} \mathrm{C}$ 区での生成量が多

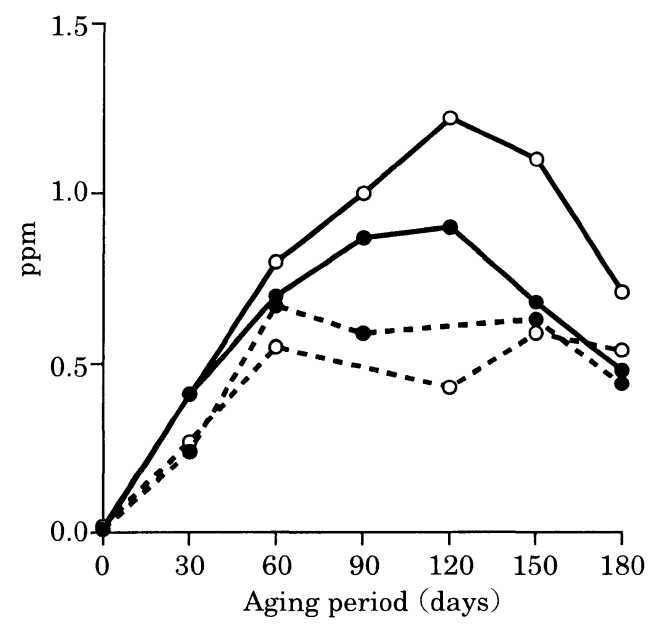

Fig. 3 Changes of the concentration of methionol in miso during the aging process

The symbols are the same as indicated in Fig. 2.

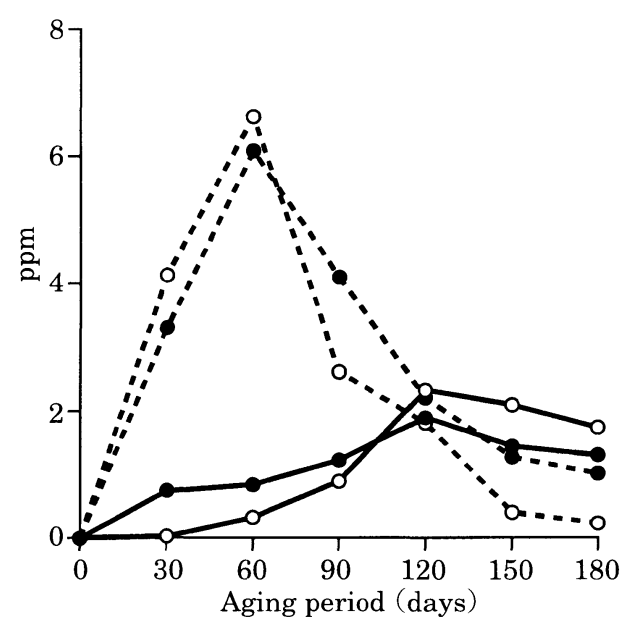

Fig.4 Changes of the concentration of HEMF in miso during the aging process

The symbols are the same as indicated in Fig. 2.

いことが明らかとなっており，HEMFはこれらの香気 成分よは異なる独自の生成機構を持つ化合物であること が示唆された。

\section{2. 蛋白溶解率, $\mathrm{pH}$ の変動亡香気成分の生成}

3 -methyl-1 -butanol, 2 -phenylethanol, methionol は 主発酵酵母の作用によって，それぞれアミノ酸のロイシ ン，フエニルアラニン，メチオニンから生成すると報

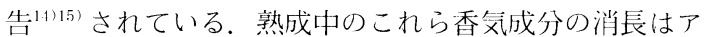
ミノ酸の変動上関連するよ推察される。 そこで熟成中の アミノ酸変動の指標として一般成分の分析值の中から蛋 白溶解率よ $\mathrm{pH}$ について注目し検討した。

味噌の味に影響を与えるとともに味増の熟成の目安と されている蛋白溶解率（全窒素（T.N.％) に対する水溶 性窒素 (W.S.N. \%) の比) の熟成中の变化を Fig. 5 に示 した．仕込み直後は硬度 $300 \mathrm{~g}$ の味噌が $25.8 \%, 700 \mathrm{~g}$ の 味増は $22.7 \%$ で約 $3 \%$ の差があった。 30 日目には全試 料で蛋白溶解率の值は急増し， $25^{\circ} \mathrm{C}$ 区が約 $50 \%, 30^{\circ} \mathrm{C}$ 区が約 $53 \%$ 上なり，温度による影響が出現した。6 60 日 目には温度による差は縮小し，それ以降は全試料とも值 に大きな变動が認められなくなり平衡状態に達した。蛋 白溶解率は仕込み後 30 日目までは熟成温度による差が 多少あったが，その後は硬度や熟成温度の影響を観察で きなかった. Fig. 6 に pH の変動を示した. $\mathrm{pH}$ の低下は アミノ酸や有機酸の生成を示しており，特にアミノ酸の 生成が 40〜 50\% 寄与しているといわれている8). pH は 


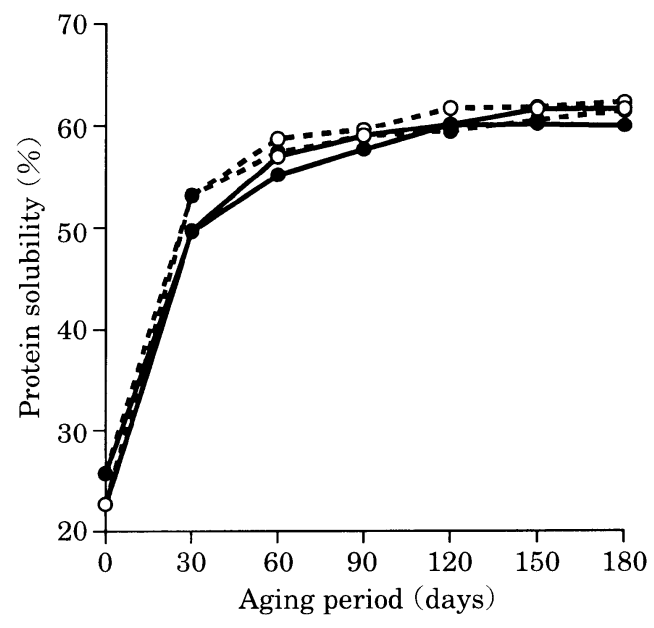

Fig.5 Changes of the rate of nitrogenous solubility in miso during the aging process

The symbols are the same as indicated in Fig. 2.

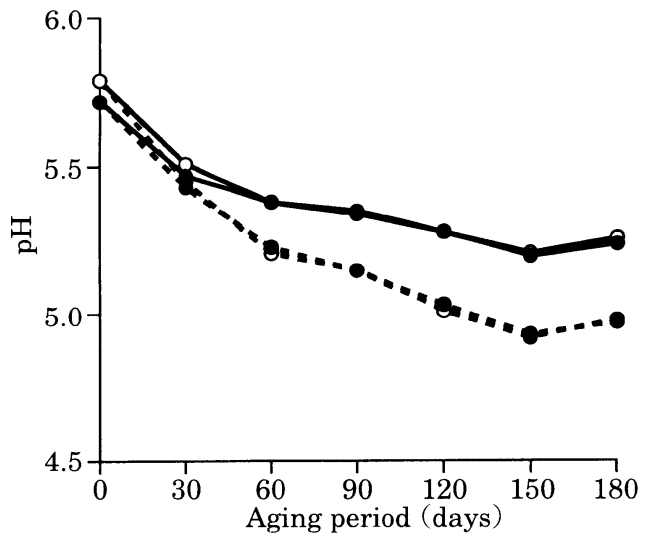

Fig.6 Changes of $\mathrm{pH}$ in miso during the aging process

The symbols are the same as indicated in Fig. 2.

仕込み時には硬度 $300 \mathrm{~g}, 700 \mathrm{~g}$ の味噌ともに約 5.7 と差 はなかった。しかし 60 日目には $25^{\circ} \mathrm{C}$ 区がともに5.4， $30^{\circ} \mathrm{C}$ 区はとむに 5.2 上熟成温度による差が出現し，その 後熟成期間が長くなるにしたがって熟成温度による $\mathrm{pH}$ 值の差は顕著になった。適度に熟成した味噌の $\mathrm{pH}$ は一 般的には 5.1〜 4.9 である.この值から熟成したと判断さ
れる時期は $25^{\circ} \mathrm{C}$ 区では 5.2 以下となった 150 日目， $30^{\circ} \mathrm{C}$ 区も 5.2 以下よなった 90 月目であり，熟成温度によって 60 日の差が認められた。

蛋向溶解率や $\mathrm{pH}$ の变動より，一般的なアミノ酸の牛 成は $30^{\circ} \mathrm{C}$ 区が $25^{\circ} \mathrm{C}$ 区より速く，量も多い推測された。

Lかし, 3-methyl-1-butanol,2-phenylethanol,methionol の濃度はともに $25^{\circ} \mathrm{C}$ 区で高く推移した。一方，本研

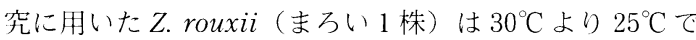
活発に発酵するという特徵がある ${ }^{10111}$ 。従って，3種の 香気成分の生成は，前駆物質となるアミノ酸の生成より これを香気成分に変換する酵母の性質に大きく影響され ると推察された。

\section{3. 色調 Y $(\%)$ の変化と HEMF の生成}

BLANK ら ${ }^{(6)}$ はアラニンと五炭糖を加熱した際のアミ ノカルボニル反応による HEMF の生成機構を提案し, HEMF はアミノカルボニル反応初期に生成した炭素数 5 の1-deoxydiketose と，アラニンのストレッカー分解 によって生成したアセトアルデヒトが結合し，環化，還 元されて生成すると報告している，著者らは，味噌の HEMF は熟成中にアミノカルボニル反応によって生成 される前駆物質に酵母が作用して形成される可能性が高 いことを報告し，HEMF の前駆物質は BLANK らが提案 した炭素数 5 の1-deoxydiketose 之同様の化合物であ ろうと想定している。 また林田ら ${ }^{(8)}$ は麦味噌では $30^{\circ} \mathrm{C}$ 以上の熟成温度で HEMF が顕著に生成されることや HEMF の形成機構 ${ }^{19220)}$ について屯著者らと同様の報告 をしている.

一方, $\mathrm{Y}(\%)$ は味噌の熟成度の判断に用いられ, 熟成 初期の急激な低下は味噌中の溶存酵素が消費されるまで の酸化に伴うもので，中期から後期の低下はアミノカル ボニル反応によるよいわれている8 .そこで, Fig. 7 に仕 込み直後から 180 日目までのY（\%)の变化を示し，味 噌熟成中のアミノカルボニル反忍の進行状況を示す指標 とし, HEMF の消長との関連を検討した。

仕込み直後の $\mathrm{Y} \%$ には硬度 $300 \mathrm{~g}$ と $700 \mathrm{~g}$ の味増間で 約 $3 \%$ の差が認められた。これは加圧蒸熟処理時間が $300 \mathrm{~g}$ の場合, $700 \mathrm{~g}$ の 2 倍以上かけられていることに起 因する。また，仙台味噌の出荷レベルである $\mathrm{Y}=12$ $15 \%$ に達した時期は， $30^{\circ} \mathrm{C}$ 区では硬度に関係なく 90 日 目であったが， $25^{\circ} \mathrm{C}$ 区では 180 日目であった。従って， $5{ }^{\circ} \mathrm{C}$ の熟成温度差は $\mathrm{Y} \%$ の值で約 90 日の熟成期間の差 となった。 また， $30^{\circ} \mathrm{C}$ 区之 $25^{\circ} \mathrm{C}$ 区の熟成温度による $\mathrm{Y}$ $\%$ の差は熟成 30 日目から 60 日目において出現した。 $30^{\circ} \mathrm{C}$ 区では，30日目以降 $\mathrm{Y} \%$ は $25^{\circ} \mathrm{C}$ 区より急速に低下 


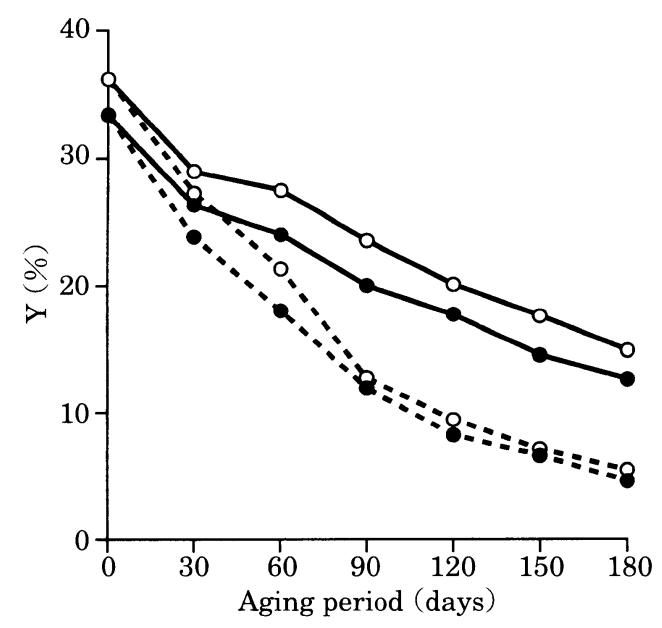

Fig.7 Changes of the value for $\mathrm{Y}(\%)$ in miso during the aging process

The symbols are the same as indicated in Fig. 2.

しており,アミノカルボニル反応の進行に差が生じてい ると判断された.

HEMF は， $30^{\circ} \mathrm{C}$ 区では 30 日目から 60 日目に急速に 多量に生成されており，Y\%の30日目以降の急激な低 下との関連が示唆された。一方, $25^{\circ} \mathrm{C}$ 区では HEMF は 120 日目までゆるやかに生成した。 $30^{\circ} \mathrm{C}$ 区の 60 日目の $\mathrm{Y}$ 值は $18.0 \%$ と $21.3 \%, 25^{\circ} \mathrm{C}$ 区の 120 日目の $\mathrm{Y}$ 值は $17.7 \%$ 之 $20.1 \%$ となり, とむに約 $20 \%$ であった. Y 值が 約 20\%にまで低下する過程でアミノカルボニル反応が 進行し, HEMF の前駆物質が生成されると推測され, 低 下する速度が速い場合に前駆物質の生成量が多くなると 推測された。

\section{要 約}

赤色辛山系米味噌の製造時における大豆の加熱処理条 件之熟成温度の熟成中の香気成分形成への影響を検討し た.

（1）赤色辛口系米味噌の熟成中の香気成分形成には熟 成温度による影響は大きかったが大豆の加熱処理条件の 影響は少なかった。

（2）赤色辛口系米味増の各種香気成分の濃度を合計し た值の $40 \sim 65 \%$ を占め, 他の醸造食品にも共通して存 在する 3-methyl-1-butanol や 2-phenylethanol の濃度 と味噌の特有香気成分の一つである methionol の濃度
は全期間を通して熟成温度 $25^{\circ} \mathrm{C}$ でやや高く推移した。

(3) 3-methyl-1-butanol,2-phenylethanol,methionol の熟成中の消長には蛋白溶解率や $\mathrm{pH}$ の変動の影響は少 なく，醉造に使用した酵母の影響が大きいことが示唆さ れた。

(4) 特有香気成分の HEMF は熟成温度 $30^{\circ} \mathrm{C}$ で形成 量が多く，他の主な香気成分の熟成中の消長と大きな差 が認められ，独自の生成機構を持つ化合物であると推測 された。

（5）熟成中の HEMF の生成は色調 Y （\%）の变化之 関連があり，Y 值で約 $20 \%$ に低下するまでは行われる ことが示唆された。

終わりに臨み，本研究を行うにあたり貴重なご助言を 下さいました岩手県工業技術センター米倉裕一氏，岩手 大学櫻井米吉名誉教授に感謝いたします.

\section{文献}

1）岩淵せつ子・柴崎一雄：日食工誌， 20, 48 (1973)

2）安平仁美: 醸協, 75，506（1980）。

3）森 隆・木内 幹: 醸協, 80, 274（1985）。

4）本間伸夫 : 醸協, 82, 471，547 (1987).

5）菅原悦子：日食工誌，38，491（1991）.

6）菅原悦子：日食工誌，38，1093（1991）.

7）菅原悦子・米倉裕一：食科工，45，323（1998）.

8）今井誠一 一松本伊左尾: 味増技術読本, 新潟県味 増工業共同組合連合会新潟県味噌技術会, 光進堂 企画 (1990).

9）松本伊佐雄 - 熊井啓治: 醸協, 93, 932 (1998).

10）高橋 清: 平成 7 年度技術部報告書, 宮城県味増 奨油工業協同組合技術部，1（1995）.

11）高橋 清: 醸協, 92，241（1997）.

12）菅原悦子 - 伊東哲雄 - 小田切敏 - 久保田紀久枝 · 小林彰夫 : 農化, 64, 171（1990）。

13）全国味増技術会：みそ技術ハンドブック付基準味 噌分析法, 昭和印刷 (1995).

14）中台忠信 : 香料, 200, 69 (1998).

15）横塚 保・佐々木正興 - 布村伸武 - 浅尾康夫 : 醇 協，75，516，717（1980）。

16) Blank, I. and Fay, L.B. : J. Agric. Food Chem., 44, 531 (1996).

17) Sugawara, E. and Sakurai, Y. : Biosci. Biotech. Biochem., 63, 749 (1999).

18）林田安生・西村賢了・J. コリンロースター：醇 協, 93，730（1998）.

19）林田安生・西村賢了・J.コリンロースター：醇 
協，94，77（1999）。

(平成 12 年 5 月 1 日受付, 平成 12 年 9 月 14 日受理)

20）林田安生・西村賢了・栗山博・J. コリンロース 夕ー: 踷研, 25, 237 (1999). 